\title{
Gastric Neuroendocrine Tumor pM1 TNM Finding v8
}

National Cancer Institute

\section{Source}

National Cancer Institute. Gastric Neuroendocrine Tumor pM1 TNM Finding v8. NCI

Thesaurus. Code C135030.

Gastric neuroendocrine tumor with distant metastasis. (from AJCC 8th Ed.) 